'Endocrinology Sector, Grupo Fleury, São Paulo, SP, Brazil

Correspondence to: José Gilberto H. Vieira Av. General Valdomiro de Lima, 508 04344-903 - São Paulo, SP, Brazil jose.vieira@fleury.com.br

Received on Oct/22/2010 Accepted on Oct/22/2010

\section{Hyperprolactinemia: new assay more specific for the monomeric form does not eliminate screening for macroprolactin with polyethylene glycol precipitation}

\author{
Hiperprolactinemia: novo ensaio, mais específico para as \\ formas monoméricas, não elimina a necessidade de pesquisa \\ de macroprolactina por precipitação com polietilenoglicol
}

José Gilberto H. Vieira', Teresinha T. Tachibana', Cláudia M. Ferrer'', José de Sá', Rosa Paula Biscolla', Ana O. Hoff', Ina Kanashiro'

$\mathrm{P}$ rolactin presents important size heterogeneity in terms of circulating molecular forms. Besides the monomer $(23 \mathrm{kDa})$, which predominates in healthy subjects as well as in patients with prolactinoma, high molecular forms are also present in low concentrations (1). These high molecular forms include $50 \mathrm{kDa}$ dimers (big prolactin) and also forms with even larger molecular weights (MW>150 kDa), known as big-big or macroprolactin. According to our current knowledge, the biological action of prolactin is almost exclusively associated with the monomeric form (2). Most of macroprolactin is related to the presence of endogenous anti-prolactin antibodies that, acting like a binding protein, prolong the half-life and block receptor binding (3).

The practical implication of these facts stems from the observation that in some individuals macroprolactin is the main circulating form, and routine assays for prolactin do not distinguish between the different size forms. This phenomenon can lead to misdiagnosis, with important clinical implications, and have been reported by several authors to be present in more than $15 \%$ of the patients with hyperprolactinemia (4).

Based on cumulative experience it is considered that best practice involves the screening for macroprolactinemia in all samples with hyperprolactinemia. The gold standard to define the presence of macroprolactinemia is gel filtration chromatography, but due to the expertise and costs involved, more simple alternatives have been developed, with polyethylene glycol (PEG) precipitation being the most used. The technique consists of measurement of prolactin in a serum sample and, when hyperprolactinemia is present, the sample is submitted to precipitation with PEG solution and the measurement is repeated in the supernatant that contains almost exclusively monomeric prolactin (5).

Experience with screening of samples with hyperprolactinemia points to the conclusion that the best way to describe normal reference ranges for prolactin may be its definition in terms of monomeric values, based on PEG precipitation (6). One additional reason for this position is the fact that different assays (nowadays different automatic platforms) recognize macroprolactin differently (7). The ideal solution would be to have assays that do not recognize macroprolactin, so that in the case of hyperprolactinemia one could trust that it represents solely monomeric hyperprolactinemia. Several publications have recently described new commercial assays with low recognition of macroprolactin (8-10). 
Until 2009, an immunofluorometric (IFMA) assay (PerkinElmer, São Paulo, Brazil) that presented high recognition of macroprolactin and with which we cumulated significant experience with PEG precipitation and chromatography $(5,11)$ was used in our routine diagnostic laboratory. Due to sample flow optimization, and bearing in mind the possibility of gaining access to one of the assays with low recognition of macroprolactin, we changed the methodology to the Beckman Coulter immunochemiluminometric assay (ICMA, Siemens Diagnostica, São Paulo, Brazil). We compared prolactin values obtained in 9,979 samples measured at our laboratory from $1^{\text {st }}$ January to $31^{\text {st }}$ March, 2008, using the IFMA, to 12,002 samples measured from $1^{\text {st }}$ January to $31{ }^{\text {st }}$ March, 2010, employing the ICMA. Arbitrarily assuming a cut-off point of 30 $\mu \mathrm{g} / \mathrm{L}$ to define hyperprolactinemia, we found 340 samples or $3.41 \%$ of all samples with hyperproplactinemia, in the IFMA group. They were all submitted to PEG precipitation and $26.2 \%$ of these samples were defined as macroprolactin positive $(0.89 \%$ of all samples). In the ICMA group we found 504 (out of 12,002) samples with prolactin higher than $30 \mu \mathrm{g} / \mathrm{L}(4.2 \%)$ and after PEG precipitation $7.5 \%$ were defined as macroprolactin positive ( $0.32 \%$ of all samples). Figure 1 depicts the number of samples (for IFMA and ICMA) with prolactin $>30 \mathrm{ng} / \mathrm{mL}$, and from these, the number tested positive for macroprolactin using the PEG method.

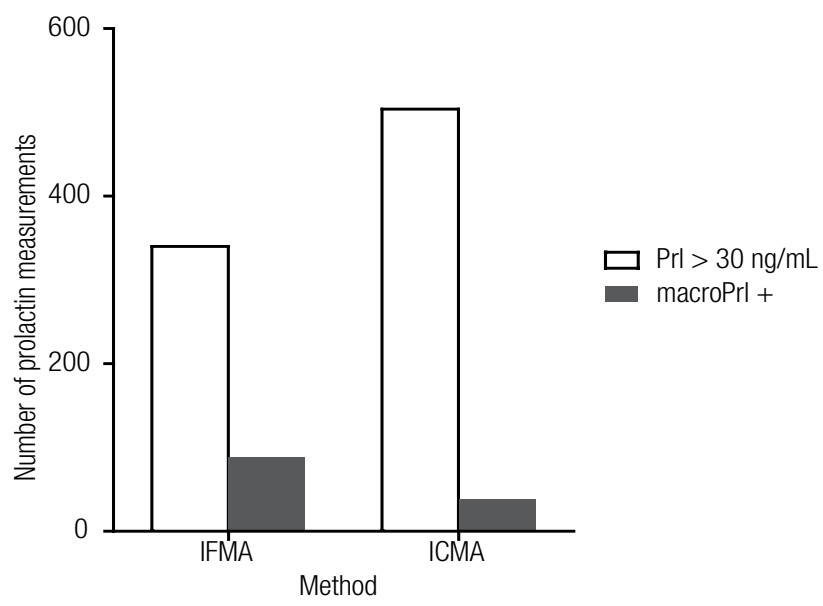

Figure 1. Number of samples with prolactin levels $>30 \mathrm{ng} / \mathrm{mL}$ using the two methods, and number of samples tested positive for macroprolactin using the polyethylene glycol (PEG) precipitation test (macroPrl+). Total prolactin measurements were 9,978 for IFMA and 12,002 for ICMA.
We have confirmed that the new assay shows lower cross-reactivity with macroprolactin $(7.5 \%$ x $25.2 \%)$, nevertheless the number of samples defined as macroprolactin is still significant. The importance of excluding the presence of macroprolactin is consensual and has profound clinical and cost implications $(12,13)$. Our data indicates the need for PEG screening for macroprolactin, even with the routine use of prolactin assay methods that present less reactivity for these large molecular weight forms.

\section{REFERENCES}

1. Suh HK, Frantz AG. Size heterogeneity of human prolactin in plasma and pituitary extracts. J Clin Endocrinol Metab. 1974;39:928-35.

2. Glezer A, Soares CRJ, Vieira JGH, Gianella-Neto D, Ribela MTCP, Goffin V, et al. Human macroprolactin displays low biological activity via its homologous receptor in a new sensitive bioassay. J Clin Endocrinol Metab. 2006;91:1048-55.

3. Hattori N, Nakayama Y, Kitagawa K, Ishihara T, Saiki Y, Inagaki C. Anti-prolactin (PRL) autoantibody-binding sites (epitopes) on PRL molecule in macroprolactinemia. J Endocrinol. 2006;190:287-93.

4. Vilar L, Moura E, Canadas V, Gusmão A, Campos R, Leal E, et al. Prevalência da macroprolactinemia entre 115 pacientes com hiperprolactinemia. Arq Bras Endocrinol Metab. 2007;51:86-91.

5. Vieira JGH, Tachibana TT, Obara LH, Maciel RMB. Extensive experience and validation of polyethylene glycol precipitation as a screening method for macroprolactin. Clin Chem. 1998;44:1758-9.

6. Beltran L, Fahie-Wilson MN, McKenna TJ, Kavanagh L, Smith TP. Serum total prolactin and monomeric prolactin reference intervals determined by precipitation with polyethylene glycol: evaluation and validation on common immunoassays platforms. Clin Chem. 2008;54:1673-81.

7. Fahie-Wilson M. Detection of macroprolactin causing hyperprolactinemia in commercial assays for prolactin. Clin Chem. 2000;46:2022-3.

8. Fahie-Wilson M, Bieglmayer C, Kratzch J, Nusbaumer C, Roth HJ, Zaninotto M, et al. Roche Elecsys Prolactin II assay: reactivity with macroprolactin compared with eight commercial assays for prolactin and determination of monomeric prolactin by precipitation with polyethylene glycol. Clin Lab. 2007;53:301-7.

9. Jassam NF, Paterson A, Lippiatt C, Barth JH. Macroprolactin on the Advia Centaur: experience with 409 patients over a three-year period. Ann Clin Biochem. 2009;46:501-4.

10. Byrne B, O'Shea P, Barrett P, Tormey W. The Beckman DxI 800 prolactin assay demonstrates superior specificity for monomeric prolactin. Clin Chem Lab Med. 2010;48:205-8.

11. Hauache OM, Rocha AJ, Maia Jr ACM, Maciel RMB, Vieira JGH. Screening for macroprolactinaemia and pituitary imaging studies Clin Endocrinol. 2002:57:327-31.

12. Gibney J, Smith TP, McKenna TJ. The impact on clinical practice of routine screening for macroprolactin. J Clin Endocrinol Metab. 2005;90:3927-32.

13. de Soárez PC, Souza MCAL, Vieira JGH, Ferraz MB. The effect of identifying macroprolactinemia on health-care utilization and costs in patients with elevated prolactin levels. Value Health. 2009;12:930-4. 